\title{
Ķīlas saistības bezstrīdus izpildīšana kā tiesiskās regulācijas mehānisma nepilnvērtīga sastāvdaḷa
}

\author{
Andris Pešudovs \\ Rīgas Stradiṇa universitāte, Doktorantūras nodaḷa, \\ Juridiskās zinātnes, Latvija \\ Andris.Peshudovs@gmail.com
}

\section{Kopsavilkums}

Pētījumā tika analizēts Civilprocesa likuma (turpmāk - CPL) 400. panta pirmās dalas 1. punkta - saistību bezstrīdus piespiedu izpildīšana piel̦aujama pēc līgumiem par saistībām, kas nodrošinātas ar publisku hipotēku vai komercḳilu - interpretācijas pamatojums, tiesību tālākveidošanas rezultātā radītais "akcesoras ḳilas saistības" jēdziens, kas vēlāk tiesību doktrīnā nostiprināts kā ḳilas devēja saistība atbildēt ḳilas apmērā. Tiesu praksē ar kiilas saistỉbu tiek pamatota CPL 400. panta pirmās daḷas 1. punktā paredzēto saistību bezstrīdus piespiedu izpildīšana kā līdzeklis atvieglotai ķīlas pārdošanai, nevis parādnieka saistību izpildei. Šādā jēdziena definēšanā tiek konstatēta neattaisnota atkāpšanās no tiesību normu teksta, un tā vērtējama kā pret likumu (contra legem) vērsts tiesību tālākveidošanas rezultāts. Lai pamatotu CPL 400. panta pirmās daḷas nozīmi kreditora piedziñas tiesības konstatēšanā, tiek ierosinātas izmaiṇas minētās panta dạıas pirmajā punktā, kas uzsvērtu publiskas ḳilas formas kā atvieglotas pierādīšanas lïdzekḷa nozīmi.

Atslēgvārdi: ḳilas tiesība, saistība, akcesora ḳilas saistība, hipotēka, komercḳila, atvieglota pierādīšana.

\section{Darba mērķis}

Pamatot tiesību doktrīnā nostiprinātā tiesību tālākveidošanas rezultāta (akcesora ķīlas saistības) neatbilstību nacionālajai tiesību sistēmai. 


\section{Materiāls un metodes}

Izpētei tika pakḷauts bezstrīdus piespiedu izpildīšanas procesuālo tiesību institūts un analizēti tajā ietvertie materiālo tiesību jēdzieni "kîilas tiesība" un "saistība", noškirot pašas materiālās tiesības no to publiski ticamās formas, tika analizēta šādas formas nozīme civilprocesā. Analizēti arī tiesu prakses materiāli. Tika salīdzināta tiesību normu vēsturiskā un aktuālā piemērošanas kārtība. Salīdzinošajai analīzei tika pakḷauts judikatūrā un tiesību doktrīnā nostiprinātais "akcesoras ḳilas saistības" jēdziens, to pretstatot Civillikumā nostiprinātajai izpratnei par "kīlas tiesību" un "saistîbu".

Saistību bezstrīdus piespiedu izpildǐšanas (turpmāk - SBPI) tiesību institūta piemērošanā visvairāk neskaidrību radījusi CPL 400. panta pirmās daḷas 1. punkta izpratne. Šis jautājums ir aktualizēts arī Latvijas Republikas Augstākās tiesas 2010. gadā veiktajā tiesu prakses apkopojumā: neskaidrības rada jautājums par to, vai bezstrīdus piespiedu izpildei pēc CPL 400. panta pirmās dal̦as 1. punkta tiek nodota pamatsaistība vai šīs saistības izpildei kalpojošã akcesorā saistība, t. i., ieḳīājuma akts ar publiskas hipotēkas vai komerckīlas statusu [7, 3]. Jau pašā problēmas uzstādījumā novērojama atkāpe no Civillikuma (turpmāk - CL) tiesību normu teksta par ḳilas tiesību kā kreditora tiesību uz ieḳīlātās lietas vērtìbu (CL 1278. p.) un kịlas tiesības kā blakus tiesiibas atkarību no prasỉjuma spēka (CL 1283. p.). Tiesību tālākveidošana, kuras ietvaros tiešā veidā ticis pārfrazēts likuma teksts, blakus tiesību pārdēvējot par blakus saistību, norāda uz būtisku atkāpi no likuma teksta gramatiskās konstrukcijas. Tiesnešu tiesības šādā veidā ir kḷuvušas par avotu jaunas tiesību normas radīšanā, kas vienlaikus mainījusi materiālajā tiesību normā definētā ḳilas institūta sastāva pazìmes (no tiesības uz saistību) un pārveidojusi CPL 400. panta pirmās dal̦as 1. punkta procesuālo nozīmi (no paātrinātas kārtības maksājuma saistību piespiedu izpildǐšanai uz paātrinātu līdzekli kịilas pārdošanai). Kā to atzīmējis E. Meļ̣kisis, juristu leksikā dažkārt sastopams izteiciens "likums nedarbojas". Tas var nozīmēt, ka ierēdnis vai amatpersona, kuras pienākumos ietilpst konkrētas normas piemērošana, vai nu vispār neveic nekādu darbību, lai to piemērotu, vai arī piemēro normu "ne tā, kā paredzēts" [8, 7]. Arī tēmas kontekstā tiek aktualizēts jautājums par likuma nepilnību un nepieciešamību grozìt tā tekstu vai par šādām izmaiṇām kā neatbilstošas piemērošanas rezultātu.

Par CPL 400. panta pirmās daḷas 1. punkta spēju "darboties", lai paātrinātā procesuālā kārtībā izpildīšanai nodotu parādnieka saistības, liecina piemēri no tiesu un tiesu nolēmumu piespiedu izpildes prakses. Lēmumus par saistību bezstrīdus piespiedu izpildīšanu, kas pieṇemti līdz 2008. gada 9. janvārim (nolēmuma datums, kad sākās izmaiṇas tiesību normu piemērošanas praksē), vieno tajos konstatētā parādnieka saistība kā juridiskais fakts parādnieka tiesību aizskāruma veidā. Līdz izmaiṇām tiesu nolēmumu rezolutīvā dala visā valsts teritorijā sistemātiski vienveidīgi tika veidota atbilstoši CPL 405. panta prasībām: piedzìt saistību bezstrīdus piespiedu izpildīšanas kārtībā pamatparādu, procentus, līgumsodu un tiesāšanās izdevumus; lēmuma izpildē piedziṇu vērst uz parādnieka kustamo, nekustamo mantu un naudas līdzekḷiem [33]; piedzìt no aizṇēmēja 
aizdevuma summu, līgumsodu, kā arī valsts nodevu; lēmums stājās spēkā nekavējoties un bija izpildāms saskaṇā ar sprieduma izpildīšanas noteikumiem [34]. Līdzīgi lēmušas arī, piemēram, Cēsu rajona tiesa [21, 22, 23], Jēkabpils rajona tiesa [31, 32], Ventspils tiesa [47] un Daugavpils tiesa [24].

Lēmumi par saistību bezstrīdus piespiedu izpildīšanu, kas pien̦emti atbilstīgi CPL 400. panta pirmā punkta 1. daḷai, lìdz 2008. gada 9. janvārim tika uzskatīti par pilnvērtīgu izpildu dokumentu un - kā to paredz CPL 405. panta trešã dalıa - tika izpildìti saskaṇā ar sprieduma izpildīšanas noteikumiem.

Secinājumu apliecina ieskats šādu lēmumu piespiedu izpildes praksē. Zvērināti tiesu izpildītāji izpildu lietvedībā neaprobežojās tikai ar piedzinnas vēršanu uz publisku hipotēku vai komerckīlu, bet piespiedu izpildes līdzekḷus lietoja arī attiecībā uz parādnieka naudas līdzekḷiem kredītiestādēs, Ceḷu satiksmes drošības direkcijā registrētu mantu, kā arī Latvijas Republikas Uzṇēmumu regiistrā reg̣istrētām parādniekam piederošām kapitāldạ̦ām.

Dobeles rajona tiesa 2006. gada 11. septembrī lietā Nr. 3-12/102 bezstrīdus piespiedu izpildǐšanai nodeva ar komercḳilu nodrošinātu parādnieka saistību, kas izriet no kredīta līguma [27]. Minētā nolēmuma piespiedu izpildei ievesta izpildu lieta Nr. 207/64-2006, kurā ietverts arī rīkojums par parādniekam piederošo naudas līdzekḷu, kas atrodas AS "Hansabanka" kontos, apḳilāšanu [41].

Analogiska situācija konstatējama par Rìgas pilsētas Ziemel̦u rajona tiesas 2006. gada 20. marta lēmuma lietā Nr. 3-12/0068/3 piespiedu izpildi, ar kuru piespiedu izpildišanai tika nodotas ar komercḳilu nodrošinātās parādnieka saistības, kas izriet no kredīta līguma [44]. Nolēmuma piespiedu izpildei ievesta izpildu lieta Nr. 97/64-2006, kuras ietvaros arī dots rīkojums par parādniekam piederošo naudas līdzekḷu, kas atrodas AS "Aizkraukles banka" kontos, apkīiaššnu [40]. Rīgas apgabaltiesas Civillietu tiesu kolēgiija 2004. gada 27. aprịḷa lēmumā lietā Nr. C04244804, apstiprinot nekustamā ìpašuma izsoles aktu, arī konstatēja: "2003. gada 14. novembrī tika ievesta izpildu lieta Nr. 605/64-2003, pamatojoties uz Rīgas rajona tiesas 2003. gada 7. novembra lēmumu, ar kuru pakḷauts bezstrīdus piespiedu izpildīšanai kredīta līgums un ḳilas (hipotēkas) līgums" [36]. Minētajā izpildu lietā vienlaikus tika dots rīkojums par parādniekam piederošo naudas līdzekḷu, kas atradās AS "Rietumu banka" kontos, apḳīlāšanu [39] un tika nosūtīts pieprasījums Latvijas Republikas Uzṇēmumu registram par parādniekam piederošo kapitāldaḷu apḳilāšanu [38]. Valstī kopumā izpildu lietās lēmumi par saistību bezstrīdus piespiedu izpildīšanu bez ierobežojumiem un izṇēmumiem no vispārējās kārtības tikuši izpildīti pilnīgā atbilstībā sprieduma izpildīšanas noteikumiem. Tiesību normu piemērošanas prakse, no vēsturiskā ieskata, lauj secināt, ka tiesas CPL 400. panta pirmās dal̦as 1. punktu ir tulkojušas līdzīgi, ievērojot šādu juridiskā siloǵisma logiisko shēmu: ja līgumi par saistībām ir nodrošināti ar publisku hipotēku vai komercḳilu, tad piel̦aujama SBPI. Šādā piemērošanas veidā tiesību norma atbilstoši reageè uz juridisku faktu, jo piespiedu izpildīšana tās civilprocesuālajā nozīmē tiek attiecināta uz saistības kā parādnieka pienākuma izpildi, savukārt publiskajai ḳilas tiesībai tiek atvēlēta 
formas kā pierādīšanu ietekmējoša (pastiprinoša) nozīme. Konstatēts ir parādnieka pienākums - saistība - un tās atbilstîba CPL izvirzìtajām publiskas ticamības prasībām. CPL 400. panta pirmās daḷas 1. punktā minēto līgumu par saistībām tiesneši pašlaik izprot citādāk, būtiski kontrastējot iepriekšējai kārtībai.

Aktuālā tiesu prakse ir atkāpusies no CPL 405. panta formālisma un SBPI tiesiskās sekas ierobežojusi ar piedziņas vēršanu uz ḳilu, nolēmumu rezolutīvo daļu konstrukcijas veidojot atbilstoši "akcesorās ḳīlas saistības" jēdziena uzstādījumiem:

- pakḷaut bezstrīdus piespiedu izpildei parādnieka saistības, kas izriet no ḳilas līguma [46];

- nodot bezstrīdus piespiedu izpildīšanai šãdas ḳilas saistības, kas nodrošina parādnieka saistību pret kreditoru pēc hipotekārā kredìta līguma par kredīta pamatsummas, procentu un lïgumsoda samaksu [29];

- nodot bezstrīdus piespiedu izpildīšanai parādnieka saistību pret kreditoru pēc hipotēkas līguma, kas nodrošina saistību pēc pamatlīguma, un piedziṇu, nepārsniedzot nostiprinātās hipotēkas apmēru, vērst uz nekustamo īpašumu [28];

- nodot bezstrīdus piespiedu izpildei saistību pēc hipotēkas līguma, kas izriet no aizdevuma līguma, vēršot piedzinu uz nekustamo īpašumu [32];

- nodot bezstrīdus piespiedu izpildei saistību starp pieteicēju un parādnieku hipotēku, kas registrēta, pamatojoties uz hipotēkas līgumu par pamatparāda, procentu un līgumsoda samaksu pēc aizdevuma līguma, parāda piedziṇu vēršot uz nostiprināto hipotēku nekustamajam ìpašumam [26].

Vienīgā tiesību normu piemērotāja metodiskā norāde par izmaiṇām CPL 400. panta pirmās daḷas 1. punkta piemērošanā, par izmaiṇu nepieciešamību un to attaisnojumu ir secinājums par nolēmumu dažādības iespējamību - tiesu prakse pirmās instances tiesu līmenī var būt un ir dažāda. Tas, ka lēmumi var atšķirties, ir iespējams un izskaidrojams, tomēr šāda prakse nav vēlama $[6,8]$. Iepriekš norādītie būtiskie fakti par SBPI piemērošanas viendabīgi sistemātisku praksi, kura ilgusi aptuveni desmit gadu, nav tikuši minēti ne CPL komentāros, ne AT 2010. gada tiesu prakses apkopojumā par SBPI, tādēl vēsturiskā normas piemērošanas kārtība, no juridiskās metodes viedokḷa, nav tikusi atspēkota kā neatbilstoša un vienlaikus nav pamatota aktuālās prakses nepieciešamība. Šādos apstākḷos iepriekš pastāvējusĩ CPL 400. panta pirmās dạlas 1. punkta izpratne savu aktualitāti saglabā arī pašlaik.

CPL 400. panta pirmās dạ̦as 1. punkta piemērošanas aktuālās interpretācijas juridiskais silogiisms nav savienojams ar normas sastāva pazīmēm. Uz šāda veida gadījumiem pilnībā attiecināms A. Grūtupa teiktais, ka sakarā ar tiesību formālo dabu jebkurai interpretācijai ir zināmas robežas. Ja pašai interpretācijai jāpatērē milzum daudz enerğijas un argumentu un interpretācijas rezultātā mēs faktiski iegūstam jau citu tiesību normu, tad ir jāmaina likums, jo šāda interpretācija savas iespējas jau ir izsmēlusi [3, 283].

Būtisko atkāpi no normas teksta un faktiski jaunas tiesiskās kārtības radīšanu publikācijā par SBPI problemātiku atzinis arī tiesību piemērotājs - ṇemot vērā minētās tiesību normas dažādo interpretāciju, Tieslietu ministrija 2010. gada 10. decembrī Saeimai 
ir nosūtījusi priekšlikumus likumprojektam "Grozījumi Civilprocesa likumā", kur arī lūgts izteikt jaunā redakcijā Civilprocesa likuma 400. panta pirmās daļas 1. punktu par SBPI pēc ḳilas līgumiem, ja tie nodrošina saistību kā publiska hipotēka vai komercḳila [6, 8]. Tomēr šāda likuma grozījumu iniciatīva palikusi bez tālākas virzības, un likumdevējs savu viedokli SBPI pakḷaut saistību ir atstājis negrozìtu, akcesorās ķīlas saistības pamatojumu atstājot tiesību tālākveidošanas līmenī.

Tiesnešu tiesību rezultāta pamatojums atrodams tiesu prakses apkopojumā CPL 400. panta pirmās dal̦as 1. punktā paredzēta procesuālā kārtība, norādot, kā izpildīt saistību, kas nodrošināta ar publisku hipotēku vai komerckīlu. Tādējādi norma pieprasa nodalīt pamatsaistību no saistības nodrošinājuma - hipotēkas vai komercḳīlas -, tā aprobežojas tikai ar tādām saistībām, kuras ir ierakstītas publiskajos reǵistros. Līdz ar to šì norma piel̦auj pakḷaut izpildīšanai pašu nodrošinājumu - komerckīlu vai hipotēku-, nevis pamatsaistību, kura ir nodrošināta ar ierakstu publiskajā reǵistrā [7, 7]. Tiesu prakses pārliecība tiesību doktrīnā papildus nostiprināta CPL komentāru veidā. Jaunais jēdziens "akcesorā ḳilas saistība" un CPL normu piemērošana tiek izskaidrota šādi: piespiedu izpildīšanai pakḷauj ḳilas līgumu iekịiātāja akcesoras saistības veidā, ja šāda saistîba tikusi nostiprināta publiskas hipotēkas vai komercḳilas formā. Nodrošinājuma saistība (ḳilas saistība) ir ḳilas devēja saistība atbildēt kīlas apmērā, aizdevuma saistības nepildǐšanas gadījumā. "Kīlas saistība" ir patstāvīgi îstenojama saistība [15, 637-638]. Argumenti par pamatsaistības nodalǐšanu no saistības nodrošinājuma nonāk pretrunā priekšnosacījumam par prasījuma nepieciešamību kīlas tiesības pastāvēšanai (CL 1280. p.). Šādā kontekstā neatbilstošs ir uzskats tikai par ķīlas līguma publiskumu, jo zemesgrāmatās ierakstāmās saistības pamatojošais dokuments (akts, no kura izriet nodrošinātais prasījums) ir tieši līgums par saistībām, piemēram, aizdevuma līgums.

Latvijas Republikas un citu Eiropas valstu tiesību doktrīnas atziṇās kịlas tiesībai vienveidīgi un viennozīmīgi tikusi piešķirta lietu tiesiska daba, saistību izpildījuma nodrošinājuma ziñā kreditoru padarot pēc iespējas neatkarīgāku no parādnieka. Saistības statusa pieškiršana ḳilai, raugoties no šāda aspekta, ir pretrunā tiesību institūta saistību izpildes nodrošināšanas mērḳim, neatbilstoša ḳilas tiesības saturam un funkcijām. Turklāt jaunais jēdziens tiesību sistēmai kopumā izrādās nelietderīgs (lieks), ja ieḳīātājs nepilda savu "akcesoro kịlas saistību", tāpat ir piel̦aujama piedziņa uz kịlu vai parādnieka mantu CPL noteiktajā kārtībā par tiesas nolēmumu piespiedu izpildi, pamatojoties uz atbilstošu juridisku faktu konstatēšanu par parādnieka saistības neizpildi.

Juridiskajā literatūrā - gan nacionālajā, gan ārvalstu - saistību tiesības kā tiesību disciplīna parasti tiek pretstatîtas lietu tiesībām. "Lietu tiesība ir absolūta, t. i., šai tiesībai ir priekšrocība salīdzinājumā ar visām citām tiesībām. Saistību tiesība ir spēkā attiecībā pret kādu konkrētu personu, turpretī lietu tiesība ir spēkā attiecībā pret jebkuru personu, un katrai personai ir pienākums atturēties no visa tā, kas varētu būt pretrunā ar attiecīgās personas lietu tiesību." $[18,8]$

"Lietu tiesību parasti saprot kā pretstatu saistību tiesībai. Tādẹl lietu tiesību būtības noskaidrošanai mēdz izlietot salīdzināšanas paṇēmienu: lietu tiesību konstatē 
ar saistību tiesību. Ar šādu paṇēmienu līdz šim noskaidrotas divas principiālas pazīmes: lietu tiesības priekšmets ir pati lieta, turpretim saistību tiesības priekšmets ir parādnieka darbība, lietu tiesība ir aizsargāta pret visiem, turpretim saistību tiesība - tikai pret otru saistības dalïbnieku." [19, 43]

Saistību tiesību un lietu tiesību atšḳirības meklējamas likumā noteiktajā šo tiesisko attiecību saturā. Saistību tiesību pamatā ir savstarpēji nodibinātas tiesiskās attiecības, kas saista divus vai vairākus to dalībniekus. Lietu tiesiskās attiecības pretstatā neietekmē tikai divas vai vairākas personas, bet rada pamatu tās ievērot visiem [1,2]. Saistību tiesības ir tādas personiska rakstura tiesības, kas uz darïjuma vai cita pamata pieder konkrētām fiziskām un juridiskām personām un kurām atbilst citu konkrētu personu pienākumi $[16,20]$.

Uz nepieciešamību nošḳirt lietu tiesību un saistību tiesību kategorijas norādījis arī N. Horns: tiesību priekšraksts, kas attiecas uz lietu tiesībām, ir pakḷauts arī vispārīgajiem lietu tiesību principiem; saistību tiesību norma tāpat ir pakḷauta šīs tiesību nozares pamatprincipiem. Šo sistēmu dạ̣ēji nodrošina pats likums. Vēl lielākā mērā tā ir tiesību zinātnes doktrīnas rezultāts. Tiesību zinātnieks, izmantojot pirkuma līguma piemēru, attiecībā uz šo sakarību norādījis, ka vācu civiltiesību abstraktuma principa ietvaros ir jāatškir divas tiesību nozares - saistību tiesības un lietu tiesības, jāatšķir pirkuma līgums un lietas nodošana [5, 227, 229]. Tāpat CPL 400. panta pirmās dal̦as 1. punktā ietvertie jēdzieni - publiska hipotēka, komercḳila un saistība - turpina ìstenot katrs savu atbilstošajā materiālo tiesību nozarē tiem piešķirto nozīmi, nodrošinot attiecīgu tiesisko seku konstatēšanas iespēju.

Jānorāda, ka tiesību vēsturē ir zināmi gadījumu, ka ḳila tikusi pieskaitīta saistību tiesību kategorijai, un šāds spilgts piemērs ir sociālistiskā tiesību sistēma. Uz šo faktu norādījis arī J. Rozenfelds: ideja par kịlas tiesību lietu tiesisko raksturu attīstījusies jau romiešu tiesībās. Ideja, ka ḳilas tiesības nav nekas cits kā vien saistību tiesību pastiprināšanas veids, radusies stipri vēlāk. Sevišḳi populāra tā kḷuvusi pagājušajā gadsimtā.

CL atspoguḷo uzskatu par ḳilas tiesību lietu tiesisko dabu, taču pastāv atšḳirīgi tiesību avoti, kuros kīlas tiesības ievietotas saistību tiesību dạ̦ā. Pie tiem piederēja arī 1993. gadā spēku zaudējušais Latvijas Civilkodekss, kā arī Krievijas Federācijas Civilkodekss $[14,8]$. Kìlas tiesības kā saistību tiesību disciplīnas sastāvdaḷas nozīme raksturota civiltiesību jautājumiem veltītajā izdevumā "Padomju Civiltiesības". K̦ỉla tajā definēta šādi: "Ḳilas tiesiskā attiecība ir akcesoriska saistība, t. i., papildsaistība, kas rodas uz likuma vai speciāla ḳilas līguma pamata. Praksē kịla parasti rodas uz līguma pamata, noslēdzot līgumu par ḳîlu. Kiilas tiesiskās attiecības dalībnieki ir ḳilas devējs un ḳilas turētājs. Ķīlas devējs (parādnieks) kīlas līgumā saskaṇā ar CK 175. p. var būt pats pamatsaistības parādnieks vai arī kāda trešā persona, kas pamatsaistībā kā puse nepiedalās, bet kas ieķīlā savu mantu, lai nodrošinātu pamatsaistības." [17, 50] N, Nemot vērā konstatēto līdzību, izdarāms secinājums, par to, ka attaisnojums pašreizējai CL 400. panta pirmās dal̦as 1. punkta piemērošanai, vismaz daḷejii, ir pamatots sociālistisko tiesību sistēmas atziṇās. Šādu gadījumu varētu uzskatīt par atkāpi dotajam solījumam 1996. gadā 
zinātniskajā pētījumā par tiesvedību Centrālajā un Austrumeiropā, ka procesuālajās tiesībās, kas pētijuma laikā pamatojās uz pielāgotiem Padomju Savienības tiesību aktiem, ir sākušās pārmaiṇas [13, 77].

E. Meḷkisis norādījis, ka sociālistiskās tiesības izauga kā nesaderīgs atzars no kontinentālās Eiropas tiesību loka un pārṇēma tā juridisko jēdzienu terminolog̣iju, daudzos gadījumos gan izmainot saturu [10, 8]. Valsts kḷuva par likuma vienīgo radītāju, tiesību un taisnības noteicēju un interpretētāju. Privātīpašums un reizē ar to tiesību sfērā arī privātās tiesības tika atceltas $[9,7]$. Toties nesalīdzināmi paplašinājās publisko tiesību nozīme. Tiesiskas valsts ideāla vietā par galamērḳi tika uzskatìta sabiedrība bez valsts un bez tiesībām. Turpretim kontinentālās Eiropas tiesību lokā tiesību norma tiek atzīta kā pārdomu rezultāts, kas daḷeji pamatojas uz prakses izpēti, dạẹji - uz taisnīguma, morāles, politikas un tiesību sistēmas harmonijas apsvērumiem [9, 10]. Situācija ar privāto tiesību institūtu izpratnes pārn̦emšanu, no tiesību viedokḷa, ir nepieņemama sociālistisko tiesību minētās specifikas dēl un sistēmiskas neatbilstības dēḷ kontinentālās Eiropas tiesību lokam. Sociālistiskā tiesību sistēma bija pazīstama ar savu zemo privāto tiesību aktualizāciju un ierobežotu civiltiesisko apgrozỉbu. Tādēl jautājumi par ḳilas tiesību problēmām nebija vieni no svarīgākajiem, pretēji atziṇām Rietumu valstu tiesību sistēmās. Turklāt minētajā izdevumā "Padomju Civiltiesības" skaidrojums par ķīlu kā akcesoru saistību pašas padomju tiesību sistēmas ietvaros ir izrādījies kḷūdains. Šāds secinājums izdarāms, iepazīstoties ar likumā izteikto ķīlas tiesības definīciju: "Kiila kā saistību izpildes nodrošinājums saistības neizpildīšanas gadijumā rada kreditoram priekšrocības tiesību saṇemt apmierinājumu no ieḳilātās mantas vērtības pirms citiem kreditoriem.” [17, 50] Norādītā izpratne būtībā atbilst aktuālajai Latvijas Republikā - ḳīla kā tiesības uz lietas vērtību. Turklāt pati definīcija izrādās ḷoti precīzi reducēta no abstraktas tiesības uz iekịlātās lietas vērtību, uz priekšroku atgūto naudas līdzekḷ u saṇemšanā.

Tiesu praksē tomēr ir atrodami piemēri, kas liecina par "akcesorās ḳilas saistības" neviennozīmīgu atzišanu. 2010. gada 29. oktobra lēmumā par SBPI Rēzeknes tiesas tiesnesis noraidīja pieteikumu un norādīja, ka hipotēkas līgumi nevar tikt pakḷauti SBPI un tajos noteiktās tiesības izlietojamas atbilstoši lietu tiesību nosacijumiem [35]. Daugavpils tiesas tiesnese 2011. gada 20. jūlijā - pretēji ieviestajai praksei - SBPI pakḷāva saistību [25]. Rīgas pilsētas Ziemelu rajona tiesa 2012. gada 20. martā noraidīja kreditora prasības pieteikumu par parāda daḷu, ko veido lēmumā par parādnieka SBPI noteiktās summas un kịlas rezultātā atgūto naudas līdzekḷ starpība. Tiesa norādīja, ka kreditors savas prasījuma tiesības pilnībā izlietojis, vēršoties tiesā ar pieteikumu par SBPI [45]. Līdzīgi prasību ir noraidījusi Rīgas pilsētas Vidzemes priekšpilsētas tiesa, norādot, ka jau pastāv spēkā esošs nolēmums ar izpildu dokumenta spēku par parādnieka saistību - pamatparāda, procentu un līgumsoda veidā - nodošanu SBPI, un šādos apstākḷos prasītājam vairs nepastāv no aizdevuma līguma izrietošas prasījuma tiesības [42]. Tā pati tiesa 2015. gada 29. jūlijā ir atteikusies pieñemt prasības pieteikumu par parāda atlikuma piedziṇu, konstatējot, ka strīdā starp tām pašām pusēm par to pašu priekšmetu un uz tā paša pamata 
jau ir spēkā esošs nolēmums par parādnieka SBPI [43]. Rìgas apgabaltiesas Civillietu tiesu kolēǵija, 2016. gada 25. janvārī izskatot lietu pēc būtības, uz SBPI konstatēto saistību un neapstrīdēto tai atbilstošo prasījumu ir atsaukusies kā uz patstāvīgu faktu tiesa konstatēja, ka prasītājs CPL 406. panta otrajā dạ̣ā noteiktajā termiṇā nav cēlis apvērsuma prasību, lai apstrīdētu AS “SEB banka” prasījumu. Tādējādi neizmantojot tiesības apstrīdēt prasījumu, prasītājs ir atzinis SBPI lēmumā nodibināto saistību un tās apmēru [37]. Latvijas Republikas Augstākā tiesa 2015. gada 31. marta spriedumā, dal̦ā noraidot kasācijas sūdzību, pamatojusies uz autora 2011. gadā pausto pārliecību [12]: iztulkojot Civilprocesa likuma 400. panta pirmās daḷas 1. punktu, pārpratumiem par tiesību normā ietverto juridisko jēdzienu "saistība" un "kīla" (hipotēka vai komercḳila) gramatisko izpratni nevajadzētu rasties, jo tie skaidri ir definēti Civillikumā un Komercḳilas likumā.

Civilprocesa likuma 400. panta pirmās dalas 1. punkts tieši norāda uz saistības pēc līguma pakḷaušanu bezstrīdus piespiedu izpildīšanai. Aizdevuma līgums nodibina saistību tiesību. Savukārt parādnieka saistību izpildes nodrošināšanai zemesgrāmatā nostiprinātā hipotēka kā ḳilas tiesība uz nekustamu īpašumu pieder lietu tiesībām. Saistībai un ḳilas tiesībai ir gan atšḳirīgi to nodibināšanas materiāli tiesiskie pamati, gan tiesiskās sekas. Tieši sekām ir izšḳiroša nozīme, jo ḳilas tiesība ir tiesība, bet saistība ir pienākums. Tāpēc, no saistību bezstrīdus piespiedu izpildī̌̌anas viedokḷa, izpildei pakḷaujams ir parādnieka pienākums, lai kreditors varētu izlietot tiesību. Nostiprinot hipotēku zemesgrāmatā, kīlas tiesība ir jau nodibināta. Tādēl, no tiesību viedokḷa, hipotēkas līguma pakḷaušana bezstrīdus piespiedu izpildīšanai ir nelietderīga. Tādējādi Civilprocesa likuma 400. panta pirmās dal̦as 1. punkta kontekstā tiesību piemērotājs saskaras ar saistību kā nodibinātas saistību tiesības tiesiskajām sekām, kas norāda uz parādnieka pienākumu kopumu un ḳilas tiesību kā lietu tiesību. Parādnieka pienākumu kopums ietver pamatparādu, procentus par sveša kapitāla lietošanu un līgumsodu. Ķilas tiesības civilprocesuālā nozīme Civilprocesa likuma 400. panta pirmās daḷas 1. punkta piemērošanas kontekstā izpaužas tikai publiskas ticamības formas piešḳiršanā civiltiesiskam darījumam. Apkopojot šeit minēto, secināms, ka, izskatot pieteikumu par saistību bezstrīdus piespiedu izpildīšanu, tiesnesim jāspriež par saistības kā civiltiesiska pienākuma izpildes pakḷaušanu piespiedu izpildei. Lai pakḷautu izpildei saistību, tiesnesim jākonstatē tās publiski ticamā forma, t. i., izpildes nodrošināšana ar kīlu [20]. Šādā kontekstā arī būtu saskatāmas publiskas hipotēkas un SBPI sistēmiskas sakarības. Publisko registru ietekme izplatās arī uz tajos ierakstītajām saistībām kā ḳīlas tiesību veidojošo saturisko pamatu un šādā veidā atvieglo saistību pierādī̌̌anu. Savukārt šādu pierādījumu sniegtās ziṇas par faktiem (saistības apmēru) neaprobežojas vienīgi ar ieḳīātās lietas vērtību vai precīzāk - šādas ziņas neietver.

Nepārliecinošā argumentācija un nepieciešamība to balstīt sociālistisko tiesību atziṇās norāda uz nespēju aktuālo interpretāciju pamatot CL un CPL tiesību normu ietvaros. 
Akcesorā ḳilas saistība ir centieni radīt tiesību institūtu, kura ietvaros ḳilas tiesības piešḳiršana kreditoram pati par sevi atvieglo ḳilas pārdošanu. Tomēr šāda jautājuma neregulěšana ir likumdevēja apzināta klusēšana. CL turpina aizsargāt ipašuma tiesības un ḳilas pārdošanu pieḷauj vienīgi izsolē ar tiesas starpniecību, ja ḳillas tiesībai papildus nav tikusi pielīgta tiesība ḳīlu pārdot par brīvu cenu (CL 1321. p.). Savukārt izsole ir dal̦a no tiesas nolēmuma piespiedu izpildes stadijas - piedziņas vēršanas uz nekustamu ipašumu, kad nepieciešama kreditora piedziṇas tiesības konstatēšana, kas neatšḳiras no piedziņas vēršanas uz jebkuru citu (neiekīlātu) parādnieka īpašumu. Turklāt CPL noteiktā kārtība nav izṇēmums. Lìdzīgs tiesiskais regulējums pastāv, piemēram, arī Francijā: piedziņas vēršanai uz ieḳīăto nekustamo ìpašumu ḳilas ṇēmējam jāievēro tāds pats process kā citiem kreditoriem $[4,568]$. CPL komentāros akcesorā kịlas saistība pamatota kā teleoloǵiskās tulkošanas metodes rezultāts $[15,637]$. Tomēr konstatētā likuma teksta pārfrazēšana ir interpretācija, kas pārsniedz normas teksta gramatiskās robežas un nav savienojama ar teleologiskās metodes rezultātu.

Šo gadījumu precīzi raksturo J. Neimaṇa norāde par tiesību tālākveidošanas veidiem un to robežām: "Izteiciens preater legem nozīmē "blakus likumam", "bez saskaņas", bet arī "bez pretrunas ar likumu”. Šāda tiesību piemērošana ir piel̦aujama tikai tad, ja likuma klusēšana kādā noteiktā jautājumā neskar apzinātu likumdevēja lēmumu. Iespējams, ka likumdevējs tieši ar savu klusēšanu ir vēlējies izteikt, ka uz problēmsituāciju nav attiecināmas noteiktas tiesiskās sekas. Šādā gadījumā tiesneša veikta tiesību tālākveidošana būtu nepiel̦aujama tiesneša sacelšanās pret likumdevēju, bet tiesneša nolēmums nostātos pret likumu. Šãdu tiesību piemērošanu apzīmē kā contra legem." [11, 15]

N̦emot vērā iepriekš konstatēto apzināto likumdevēja klusēšanu, kịlas tiesības lietošanu saistot tikai ar piedziṇas vēršanu uz ieḳilāto lietu vispārējā kārtībā, kāda paredzēta nolēmumiem par parāda piedziṇu, CL definēto "blakus tiesību" pārdēvējot par "blakus saistību", faktiski tiek īstenota likumam pretēja tiesību tālākveidošana.

CPL 400. panta pirmās daḷas 1. punkta pareizai interpretācijai ḳilas tiesību nepieciešams atšķirt no tiesības prasīt izpildỉjumu (piedziņas tiesības). Uz šo būtisko apstākli, Latvijas civiltiesisko kārtību salīdzinot ar Vāciju, norādījis N. Vīnzarājs: ḳīlas tiesība ir tikai tiesība uz lietas vērtību, bet nevis arī tiesība uz parādnieka izpildījumu jeb parāda samaksu. Jākonstatē, ka, pēc vācu civillikuma, kīlas tiesība ir ìpašs saliktenis no reālsaistības un tiesības uz aprobežotu valdījumu, turpretim, pēc mūsu tiesībām, kīlai nav reālsaistības elementa [19, 59]. Šādā kontekstā arī izpaužas akcesorās ḳillas saistības nepilnība, jo uzmanība civilprocesuālā nozīmē tiek pievērsta tikai pašam nodrošinājumam - CPL 400. panta pirmās daḷas 1. punkts piel̦auj pakḷaut izpildī̌anai publisko saistību, t. i., pašu nodrošinājumu - komercḳillu vai hipotēku, nevis pamatsaistību, kura ir nodrošināta ar ierakstu publiskajā registrā $[7,7]$. Secinājums nevar būt pilnībā pamatots, jo paša nodrošinājuma konstatēšana tiesību sistēmas ietvaros nav pielīdzināma piedzin̦as tiesības pastāvēšanai. Savukārt tieši piedziṇas tiesības atzî̌ana tiesas nolēmumā ir nepieciešama prasība piedziṇas vēršanai uz parādnieka mantu (tajā skaitā - 
ieḳīātu). Publiskas ḳīlas nozīme SBPI izpaužas nevis pašas kreditora ḳīlas tiesības (ieḳīātāja akcesorā pienākuma) konstatēšanā, bet šāda publiska ḳilas forma ir izmantojama SBPI nododamās parādnieka saistības pierādīšanā. Turklāt CL satur tiešas norādes atvieglotas pierādīšanas iespējai. Atbilstoši CL 1280. pantam katrā ḳilas tiesībā ir nepieciešams prasījums, par ko ḳila atbild [2].

N̦emot vērā CL nostiprināto sakarību un publiskas ḳilas formas radītās iespējas pierādīšanas atvieglošanā, autors pamato šādu deduktīvas spriešanas virzību - tieši pieñēmums par spēkā esošu publisku ḳilu, rada pamatu secinājumam par iespēju SBPI nododamas saistības pastāvēšanai.

\section{Secinājumi}

Akceseorās ḳilas saistības jēdziena definēšana ir vērtējama kā būtiska atkāpe no tiesību normu teksta gramatiskās izpratnes (CL definētās ḳilas tiesības un saistības sastāva pazīmēm), kas CPL 400. panta pirmās dalıas 1. punkta gadỉjumā SBPI no procesuālā līdzekḷa saistību piespiedu izpildīšanai ir pārveidojusi par atvieglotu kārtību ḳilas pārdošanai. Likumā nostiprinātie ḳilas tiesības lietošanas nosacījumi, paredzot ierobežotu kārtību, kas saistāma tikai ar atbilstošas kreditora piedziņas tiesības konstatēšanu, ir uzskatāmi par likumdevēja apzinātu klusēšanu, bet tiesību tālākveidošanas rezultāts akcesoras ḳilas saistības veidā nostājas pret likumu (contra legem).

Lai saglabātu CL definēto jēèienu "ḳilas tiesība" un "saistība" izpratni arī parādnieka piedziñas tiesības konstatēšanā SBPI ietvaros, autors piedāvā precizēt CPL 400. panta pirmās daḷas 1. punktu, to izsakot šādā redakcijā: "saistību bezstrīdus piespiedu izpildǐšana piel̦aujama pēc līgumiem par saistībām, kas pamatotas ar ierakstiem Zemesgrāmatā vai Komercḳilu reg̣istrā". Šādā veidā 400. panta pirmās dalıs ietvaros tiek ievērota piespiedu izpildī̌nanai pakḷauto saistību klasifikācija atbilstoši to formas radītajiem atvieglotajiem pierādī̌̌anas līdzekḷiem: publiskā reǵistrā (Zemesgrāmatā, Komercḳīlu reǵistrā) ierakstītām saistībām, notariāli apliecinātiem līgumiem, notariāli apliecinātiem vai zemesgrāmatā ierakstītiem nomas vai īres līgumiem, protestētiem vekseḷiem. Kā arī tiek novērsta cita akcesorās ḳillas saistības radītā nepilnība, kas pieprasa papildu tiesvedību par parāda atlikumu pēc ḳilas pārdošanas.

Uztverot publisko formu tikai kā pierādīšanas līdzekli, atkrīt nolēmuma aprobežošana ar ieḳīātās lietas vērtību. Lēmums par SBPI kā individuālais tiesību piemērošanas akts aptver visu parādnieka atbildības apjomu. Šādā veidā tiek radīta iespēja pilnīgai CPL 406. pantā paredzētajai dispozitivitātes izpausmei, un šādu tiesību neizmantošana kā sacīkstes principu leǵitīmi ierobežojošs procesuāls elements vienlaikus tiek uzskatīta par pamatu SBPI pakḷautā prasījuma atzīšanai, tāpat kā pārējos CPL 400. panta pirmās dal̦as bezstrīdus izpildes gadijumos. 


\section{Undisputed Enforcement of the Pledge Obligation as an Incomplete Component of the Legal Regulation Mechanism}

\section{Abstract}

The article analyses justification of the interpretation of Section 400 (1) (1) of the Civil Procedure Law (hereinafter - CPL) - undisputed enforcement of obligations is permitted pursuant to agreements regarding obligations which are secured with a public mortgage or a commercial pledge, the concept of accessory pledge obligation, formed as a result of further development of law that later in the legal doctrine has been established as obligation of the pledge provider to be liable in the pledge amount. Within the framework of judicial practice undisputed enforcement of obligations under Section 400 (1) (1) of CPL is justified as a means of simplified sale of pledge, not enforcement of the debtor's obligations. Definition of such a concept states unjustified deviation from the text of legal provisions that is viewed as a contra legem (against the law) result of further development of law.

For purpose of justifying the meaning of Section 400 (1) of CPL in identifying the enforcement right of the creditor, it is proposed to make amendments to Clause 1 of Paragraph 1 of the given section that would emphasise the meaning of a public pledge form as a simplified means of proof.

Keywords: pledge right, obligation, accessory pledge obligation, mortgage, commercial pledge, simplified proof.

\section{Literatūra}

1. Akkermans, B. The Principles of Numerus Clausus in European Property Law. Portland: Oxford, 2008, 2.

2. Civillikums. Trešã dal̦a. Lietu tiesības. Valdïbas Vēstnesis, 44, 24.02.1937. Iegūts no: http:// likumi.lv/doc.php?id=90221 [sk. 18.06.2015.].

3. Grūtups, A. Tiesu prakse un komentāri. Rīga: Mans Īpašums, 1994.

4. Herzog, P. Civil procedure in France. Columbia University School of Law Project on International Procedure. The Hague: Springer Science + Business Media Dordrecht, 1967.

5. Horns, N. Ievads tiesību zinātnē un tiesību filosofijā. Likums un Tiesības. 2000, 8(12), 227, 229.

6. Jonikāns, V. Dažas piezīmes par saistību bezstrīdus piespiedu izpildīšanas problēmām. Jurista Värds. 2011, 7, 8.

7. Latvijas Republikas Augstākās tiesas 2010. gada apkopojums par tiesu praksi saistību bezstrīdus piespiedu izpildīšanā. Latvijas Republikas Augstākā tiesa. Iegūts no: http://at.gov. lv/lv/judikatura/tiesu-prakses-apkopojumi/civiltiesibas/ [sk.12.10.2016.]. 
8. Mel̦kisisis, E. Juridiskās metodes pamati. 11 soḷi tiesību normu piemērošanā. Rīga: BO SIA Ratio iuris, 2003.

9. Meḷ ḳisis, E. Kontinentālās Eiropas tiesību loks rietumu tiesībzinātnieku skatījumā. Juristu Žurnāls. 1998, 6, 7.

10. Meḷkisis, E. Tiesību normu abstraktums un tā sekas. Juristu Žurnāls. 1998, 8, 8-9.

11. Neimanis, J. Tiesību tālākveidošana. Rīga: Latvijas Vēstnesis, 2006.

12. Pešudovs, A., Vitovskis, V. Saistību bezstrīdus piespiedu izpildī̌̌anas problēmas II. Jurista Vārds. 2011, 5, 12.

13. Rivkin, D. W., Platto, C. Litigation in Central and Eastern Europe. London: Kluwer Law International, 1996.

14. Rozenfelds, J. Kìlas tiesības. Rīga: Zvaigzne ABC, 1998.

15. Torgāns, K. Civilprocesa likuma komentāri. II daḷa. Rīga: Tiesu namu aǵentūra, 2012.

16. Torgāns, K. Saistību tiesības. Rīga: Tiesu namu aǵentūra, 2014.

17. Vēbers, J., Torgāns, K., Šulcs, V. Padomju Civiltiesības. Rīga: Zvaigzne, 1986.

18. Višnnakova, G., Balodis, K. Latvijas Republikas Civillikuma komentāri. Lietas, valdījums, tiesības uz svešu lietu. Rịga: Mans İpašums, 1998.

19. Vīnzarājs, N. Civiltiesību problēmas. Rīga: E. Kalniṇa, V. Tihonova izd., 2000.

\section{Tiesu un tiesu izpildītāju dokumenti}

20. Augstākās tiesas Civillietu departamenta 2015. gada 31. marta spriedums lietā Nr. C31230009.

21. Cēsu rajona tiesas 2003. gada 14. augusta lēmums lietā Nr. 3-9/51-111-03.

22. Cēsu rajona tiesas 2004. gada 28. jūlija lēmums lietā Nr. 3-9/51-144-04.

23. Cēsu rajona tiesas 2008. gada 5. jūnija lēmums lietā Nr. 3-12/0400-08.

24. Daugavpils tiesas 2005. gada 9. decembra lēmums lietā Nr. 3-12/0737.

25. Daugavpils tiesas 2011. gada 20. jūlija lēmums lietā Nr. 3-12/0900/2011.

26. Daugavpils tiesas tiesneses zemesgrāmatu nodaḷā 2013. gada 24. aprīḷa lēmums lietā Nr. 3-12/0408.

27. Dobeles rajona tiesas 2006. gada 11. septembra lēmums lietā Nr. 3-12/102.

28. Gulbenes rajona tiesas zemesgrāmatu nodaḷas tiesneses 2012. gada 2. aprīla lēmums lietā Nr. 3-12/0076.

29. Jelgavas tiesas zemesgrāmatu nodạ̦as tiesneses 2012. gada 22. marta lēmums lietā Nr. 3-12/0524.

30. Jēkabpils rajona tiesas 2007. gada 14. marta lēmumā lietā Nr. 3-12/0105.

31. Jēkabpils rajona tiesas 2008. gada 20. marta lēmums lietā Nr. 3-12/287.

32. Jēkabpils rajona tiesas zemesgrāmatu nodaḷas tiesneses 2012. gada 2. marta lēmums lietā Nr. 3-12/0137.

33. Kuldīgas rajona tiesas 2008. gada 27. oktobra lēmums lietā Nr. 3-12/0571/3.

34. Madonas rajona tiesas tiesneša D. P. Kḷaviṇa 2008. gada 10. novembra lēmums.

35. Rēzeknes tiesas 2010. gada 29. oktobra lēmums lietā Nr. 3-12/1388.

36. Rīgas apgabaltiesas Civillietu tiesas kolēgijas 2004. gada 27. aprīḷa lēmums lietā Nr. C04244804.

37. Rīgas apgabaltiesas Civillietu tiesu kolēgijas 2016. gada 25. janvāra spriedums lietā Nr. C33467813.

38. Rīgas apgabaltiesas iecirkṇa zvērināta tiesu izpildītāja pieprasījums izpildu lietā Nr. 605/64-2003.

39. Rīgas apgabaltiesas iecirkṇa zvērināta tiesu izpildītāja rīkojums izpildu lietā Nr. 605/64-2003.

40. Rīgas apgabaltiesas iecirkṇa zvērināta tiesu izpildītāja rīkojums izpildu lietā Nr. 97/64-2006. 
41. Rīgas apgabaltiesas iecirkṇa zvērināta tiesu izpildītāja rīkojums izpildu lietā Nr. 207/64-2006. 42. Rīgas pilsētas Vidzemes priekšpilsētas tiesas 2012. gada 21. marta spriedums lietā Nr. C30618710. 43. Rīgas pilsētas Vidzemes priekšpilsētas tiesas 2015. gada 29. jūlija lēmums Nr. 3-10/0371/4. 44. Rīgas pilsētas Ziemeḷu rajona tiesas 2006. gada 20. marta lēmums lietā Nr. 3-12/0068/3. 45. Rìgas pilsētas Ziemel̦u rajona tiesas 2012. gada 20. marta spriedums lietā Nr. C32287211. 46. Valmieras rajona tiesas 2009. gada 17. jūlija lēmums lietā Nr. 3-12/1702-09.

47. Ventspils tiesas 2005. gada 6. aprīla lēmums lietā Nr. 3-12/0059. 